\title{
Characterization of Halo Blight Races on Dry Beans in South Africa
}

\author{
D. Fourie, ARC-Grain Crops Institute, Private Bag X1251, Potchefstroom 2520, South Africa
}

\begin{abstract}
Fourie, D. 1998. Characterization of halo blight races on dry beans in South Africa. Plant Dis. $82: 307-310$

Isolates of the halo blight pathogen Pseudomonas syringae pv. phaseolicola were collected in the bean-producing areas in South Africa from 1991 to 1996. Of the 1,128 isolates collected, 967 were identified as $P$. syringae pv. phaseolicola. The majority of these isolates were obtained from a wide range of Phaseolus vulgaris cultivars, and the rest from $P$. coccineus and $P$. lunatus. Two hundred fifty-five isolates, representative of all the localities and cultivars sampled, were categorized into different races according to their reaction on a set of differential cultivars. Seven races $(1,2,4,6,7,8$, and 9) were identified, with race 8 the most prevalent. Races 1, 2, 6, and 8 were widely distributed through the whole production area, while races 4,7 , and 9 were restricted to one or two localities.
\end{abstract}

Halo blight, caused by Pseudomonas syringae pv. phaseolicola (Burkh.) Dows., is an important seed-borne disease of dry beans (Phaseolus vulgaris L.; 1,3). The disease is a major constraint of dry bean production in South Africa, especially in the moderate to cooler areas of the country. The extent of yield losses has not yet been estimated, but the disease occurs on all commercial cultivars and in the entire dry bean production area.

Several races of $P$. syringae pv. phaseolicola have been reported world-wide. Races 1 and 2 have originally been described in the United States by Patel and Walker (9) on their reaction to the cultivar Red Mexican U13. These races have since been reported from several other countries $(3,6,13,17)$. A third race from Africa was identified on the basis of its reaction to $\mathrm{cv}$. Tendergreen $(8,14)$. Recently, Taylor et al. (15) extended the range of differentials to eight cultivars and lines, and accordingly identified nine races of $P$. syringae pv. phaseolicola. Races 1 and 2 have previously been reported in South Africa $(2,5)$ on the basis of their reaction to Red Mexican U13. The aim of this study was to identify local races by using the extended range of cultivars, and to determine their geographic distribution.

\section{MATERIALS AND METHODS}

Sampling and isolation of bacteria. Leaves and pods of dry beans with halo

Corresponding author: D. Fourie

E-mail: deidre@ops1.agric.za

This project has been funded by the Dry Bean Producers Organization of South Africa.

Accepted for publication 19 November 1997.

Publication no. D-1998-0119-01R

(C) 1998 The American Phytopathological Society blight symptoms were collected from the major bean-producing areas in South Africa from 1991 to 1996. Samples were taken from various cultivars of Phaseolus vulgaris, $P$. coccineus L. (large white kidney beans), and $P$. lunatus L. (lima beans), and were collected from 255 disease occurrences. Prior to isolation, pods and leaves were rinsed under running tap water for 10 min, then surface-sterilized by soaking materials for $3 \mathrm{~min}$ in $3.5 \%$ sodium hypochlorite and rinsing them twice in sterile water for $1 \mathrm{~min}$ each. Bacteria were isolated using the method of Schaad (11) and streaked onto King's B medium (7). After incubation for $48 \mathrm{~h}$, fluorescent colonies were selected under UV light and purified on King's B medium by a series of single colony transfers. Non-fluorescent colonies reminiscent of Pseudomonas in culture were additionally selected for further identification. All isolates are maintained at $-72^{\circ} \mathrm{C}(12)$.

Identification of isolates. Carbon source utilization of mannitol, sorbitol, and inositol, oxidase test, and levan production (11) as well as symptomology on leaves of cv. Canadian Wonder (a universal susceptible cultivar) were used to confirm the identity of isolates. Antiserum specific to $P$. syringae pv. phaseolicola was provided by Nigel Lyons, of the Horticultural Research International (HRI), Wellesborne, England, during the latter part of the study, and was additionally used to confirm the identity of isolates using the method of Taylor (13).

Race identification. Two hundred fiftyfive isolates, representative of all the localities and cultivars sampled, were randomly selected for identification of races (Table 1). Seven reference cultures (1302A, 1299A, 2709A, 882, 1281A, 1449B, and 2656A) of $P$. syringae pv. phaseolicola (16), obtained from Dr. Nigel Lyons, were included for comparison to the races in South Africa. The isolates were kept on King's B agar slants at $4^{\circ} \mathrm{C}$ for the duration of the study.

Races were identified according to their reaction on a set of differential dry bean cultivars and lines $(15,16)$. Seeds of the differential set were planted in $8-\mathrm{cm}$ diameter plastic pots in sterile soil and maintained in a greenhouse on a 12-h day/night cycle of 27 and $19^{\circ} \mathrm{C}$, respectively. Seeds from cv. 1072 were treated with $98 \%$ sulfuric acid for $30 \mathrm{~min}$ and kept overnight in moist paper rolls to germinate. For each isolate, 3 seeds were planted per pot and 3 pots used per differential. Pots were randomized prior to inoculation.

Inoculum was prepared by suspending a 24- to 48-h-old culture in sterile distilled water and adjusting it turbimetrically to contain approximately $10^{8} \mathrm{CFU} / \mathrm{ml}$. Seedlings, 7 to 10 days old, with fully expanded primary leaves were used for inoculation. Plants were inoculated with a DeVilbiss atomizer by spraying the bacterial suspension in two small areas $(0.5-\mathrm{mm}$ diameter) to either side of the midrib onto the abaxial surface of the leaves, thereby forcing the bacteria into the leaf tissue $(15,16,18)$. The whole leaf area was then sprayed with the bacterial suspension until completely wet. Control plants were inoculated with sterile distilled water. Inoculated plants were kept in a humidity chamber $\left(19 \pm 1^{\circ} \mathrm{C}\right.$, relative humidity $[\mathrm{RH}]=100 \%$ ) for $48 \mathrm{~h}$ before being transferred to a greenhouse equipped with a humidifier $\left(18^{\circ} \mathrm{C}\right.$ night, $25^{\circ} \mathrm{C}$ day, $\mathrm{RH}=70 \%$ ). Plants were rated for infection 10 days after inoculation on a 1 to 5 scale $(15,16)$, with 1 being highly resistant and 5 being highly susceptible.

Leaf vs. pod inoculation. Of the isolates selected for race identification, 27 were inoculated onto pods to compare whether pods and leaves react similarly to a specific race. Bacterial suspensions $\left(10^{8}\right.$ $\mathrm{CFU} / \mathrm{ml}$ ) were inoculated onto young attached pods of the differential set with a hypodermic needle using the modified method of Cheng et al. (4). Sterile distilled water was used for control inoculations. Inoculated plants were maintained in a greenhouse $\left(19^{\circ} \mathrm{C}\right.$ night, $27^{\circ} \mathrm{C}$ day, $12-\mathrm{h}$ day length). Pods were rated for lesion development 10 days after inoculation.

\section{RESULTS}

Identification of isolates. A total of 1,128 isolates were examined during the study. Of these, 967 were identified as $P$. syringae pv. phaseolicola. These isolates tested positive for levan, negative for the oxidase test, and did not utilize mannitol, sorbitol, and inositol as sole carbon 
sources. Water-soaked lesions developed when they were inoculated onto cv. Canadian Wonder. Systemic chlorosis as a result of toxin translocation was also noted. Agglutination was observed with isolates tested with the antiserum specific to $P$. syringae pv. phaseolicola. A small percentage $(2 \%)$ of the identified isolates were unable to produce fluorescent pigment on King's B medium, and two isolates produced a brown diffusible pigment as described by Mabagala and Saettler (8) and Taylor et al. (15).

Race identification. Seven races of $P$. syringae pv. phaseolicola were identified in South Africa (Fig. 1). Of these, race 8 was the most prevalent (46.3\%), while races 1,2 , and 6 constituted $27,6.3$, and $18.6 \%$ of the isolates, respectively. Only four isolates of races 7 and 9 and one isolate of race 4 were found. Races 3 and 5 have not been identified from South African isolates of $P$. syringae pv. phaseolicola. The two isolates which produced a brown diffusible pigment on King's B belonged to race 1 and 6 .

Race 8 was widely distributed and occurred in most of the localities sampled (Table 1). Race 1 was initially (during survey of 1991 to 1993 ) found only in the
Mpumalanga Highveld, where large white kidney beans are cultivated, but has since spread to new areas. Race 7 was confined to KwaZulu-Natal where it had been isolated from two localities (Cedara and Greytown), and race 9 was only found in KwaZulu-Natal and Mpumalanga. Although the occurrence of races 2 and 6 was low, these races were widespread throughout the production areas (Table 1).

The races identified were isolated from a wide variety of Phaseolus vulgaris and some $P$. coccineus and $P$. lunatus cultivars (Table 2). All seven races were identified from large-seeded $P$. vulgaris cultivars. Five of the seven races were found on Wartburg, four races on Bonus, SSB 10, 30 , and 40, and green beans, while Stormberg, Umlazi, and breeding trials hosted three races each. The rest of the largeseeded cultivars were associated with one race only. Four races were identified from small-seeded $P$. vulgaris cultivars, three from $P$. coccineus, and one race from $P$. lunatus (Table 2). All three races from $P$. coccineus (races 1, 6, and 8) were found on cv. SSN1, while race 6 was isolated from SSN1, Bomba, and Egyptian Great. Only one isolate, belonging to race 2 , was found on P. lunatus.
Isolates from race 8 were identified from the majority of cultivars, while isolates belonging to races 1,2 , and 6 were also identified on a wide range of cultivars (Table 2). Race 4 was only found on imported kidney beans, race 7 on cv. Drakensberg, and race 9 on cv. Umtata. Eighteen isolates consisting of races $1,2,6,8$, and 9 were collected from cultivars of which the names are unknown.

Leaf vs. pod inoculation. Of the 27 isolates inoculated onto pods of the differential set, 17 gave similar race identifications as when inoculated onto primary

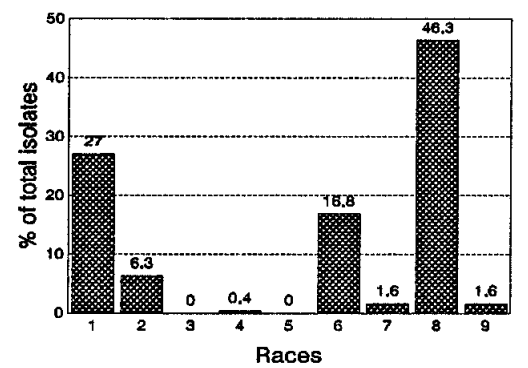

Fig. 1. Races of Pseudomonas syringae pv. phaseolicola occurring on dry beans in South Africa.

Table 1. Origin of Pseudomonas syringae pv. phaseolicola isolates selected for race identification

\begin{tabular}{|c|c|c|c|c|}
\hline Host & & & Number of isolates & Races detected \\
\hline Phaseolus. vulgaris & Gauteng & Arnot & 14 & $1,6,8$ \\
\hline P. vulgaris & & Bapsfontein & 1 & 8 \\
\hline P. vulgaris, $P$. coccineus & & Delmas & 41 & $2,6,8$ \\
\hline$P$. vulgaris, $P$. coccineus & & Nigel & 8 & $1,6,8$ \\
\hline$P$. vulgaris, $P$. coccineus & & Ogies & 7 & 1,8 \\
\hline P. vulgaris & & Pretoria & 6 & $2,4,8$ \\
\hline P. vulgaris & Free State & Bethlehem & 4 & 1 \\
\hline P. vulgaris & & Bloemfontein & 1 & 1 \\
\hline P. vulgaris & & Bothaville & 4 & 6 \\
\hline P. vulgaris & & Bervie & 1 & 1 \\
\hline P. vulgaris & & Fouriesburg & 1 & 8 \\
\hline P. vulgaris & & Reitz & 1 & 8 \\
\hline P. vulgaris & & Warden & 1 & 8 \\
\hline P. vulgaris & & Kransfontein & 4 & 1,6 \\
\hline P. vulgaris & Mpumalanga & Burgershall & 2 & 2,8 \\
\hline P. vulgaris, $P$. coccineus & & Ermelo & 39 & $1,2,6,8$ \\
\hline P. vulgaris & & Groblersdal & 1 & 6 \\
\hline$P$. vulgaris, $P$. coccineus & & Hendriena & 5 & 1 \\
\hline P. vulgaris & & Kendal & 1 & 8 \\
\hline$P$. vulgaris, $P$. coccineus & & Kriel & 12 & $1,6,8,9$ \\
\hline$P$. vulgaris, $P$. coccineus & & Leslie & 4 & 1,6 \\
\hline$P$. vulgaris, $P$. coccineus & & Lothair & 3 & 1 \\
\hline P. vulgaris & & Lydenburg & 1 & 6 \\
\hline P. vulgaris & & Middelburg & 5 & $1,2,8$ \\
\hline P. vulgaris & & Van Wyksdrif & 1 & 8 \\
\hline$P$. vulgaris, $P$. coccineus & & Vlakfontein & 2 & 1,6 \\
\hline P. vulgaris & & Komatipoort & 9 & $1,6,8$ \\
\hline$P$. vulgaris & Northwest & Carletonville & 5 & $1,2,8$ \\
\hline$P$. vulgaris, $P$. coccineus, $P$. lunatus & & Lichtenburg & 7 & 6 \\
\hline P. vulgaris & & Potchefstroom & 10 & 1,8 \\
\hline P. vulgaris & KwaZulu-Natal & Cedara & 4 & 1,7 \\
\hline P. vulgaris & & Greytown & 12 & $6,7,8,9$ \\
\hline P. vulgaris & & Makatini & 9 & 1 \\
\hline P. vulgaris & & Normandien & 2 & 6,8 \\
\hline P. vulgaris & & Niekershoop & 1 & 8 \\
\hline P. vulgaris & Cape Province & Douglas & 2 & 6 \\
\hline P. vulgaris & & George & 4 & 1,8 \\
\hline P. vulgaris & & Klein Karoo & 3 & 1 \\
\hline P. vulgaris & & Kokstad & 5 & 8 \\
\hline P. vulgaris & & Kimberley & 1 & 2 \\
\hline
\end{tabular}


leaves. These included isolates that belong to races $1,2,6,7$, and 8 . Based on their reaction to cultivar A43, eight isolates were identified as race 8 when inoculated onto leaves, but appeared to be race 6 when inoculated onto pods. These isolates produced only a trace of water-soaking at the inoculation point on leaves of cv. A43 and were rated 2 on the infection rating scale $(15,16)$, but produced water-soaked lesions on pods. Two isolates identified as race 1 on leaves also showed to be race 6 when inoculated onto pods. Only a trace of water-soaking (infection rating $=2$ ) was also observed on inoculated leaves of cvs. Red Mexican and Guatemala 196-B, but water-soaked lesions were clearly visible on pods.

\section{DISCUSSION}

Seven races of $P$. syringae pv. phaseolicola occurring on dry beans in South Africa were identified in this study. Previously, only race 1 and race 2 have been reported from this country $(2,5)$. The increased number of races occurring locally could be contributed either to the introduction of new races into South Africa, or the subdivision of the three previously described races $(2,3,5,6,8,9,15-17)$ into 9 different races by using the extended range of differentials $(15,16)$. Also, the current study includes more isolates from more cultivars and a larger geographical area than those reported by Boelema (2) and Edington (5).

One race (race 8) dominated the South African population of $P$. syringae pv. phaseolicola. This is consistent with the results of Taylor et al. (15), who found race 8 mainly in Lesotho and Southern Africa. It, therefore, appears that this race might

Table 2. Host range of Pseudomonas syringae pv. phaseolicola races in South Africa

\begin{tabular}{|c|c|c|c|c|c|c|c|c|c|c|}
\hline \multirow[b]{2}{*}{ Species/cultivar } & \multicolumn{10}{|c|}{ Races } \\
\hline & 1 & 2 & 3 & 4 & 5 & 6 & 7 & 8 & 9 & Total \\
\hline \multicolumn{11}{|l|}{ Phaseolus vulgaris } \\
\hline \multicolumn{11}{|l|}{ Large-seeded } \\
\hline Allubia Cerrillos & & & & & & & & 1 & & 1 \\
\hline And 888 & & & & & & & & 1 & & 1 \\
\hline Atoki & & 1 & & & & & & 1 & & 2 \\
\hline Bonus & 23 & 1 & & & & 5 & & 7 & & 36 \\
\hline Breeding trials & 1 & & & & & 9 & & 16 & & 26 \\
\hline Broad acres & & & & & & 1 & & & & 1 \\
\hline Drakensberg & & & & & & 1 & 4 & & & 5 \\
\hline Green beans & 3 & 2 & & & & 1 & & 16 & & 22 \\
\hline Jenny & & & & & & 2 & & & & 2 \\
\hline Kid 27, 28, 35 & & & & & & & & 3 & & 3 \\
\hline Kidney beans & & & & 1 & & & & & & 1 \\
\hline Leeukop & & & & & & & & 3 & & 3 \\
\hline Limpopo & 1 & & & & & & & & & 1 \\
\hline Montcalm & & & & & & & & 1 & & 1 \\
\hline Natal speckled sugar & 2 & & & & & & & & & 2 \\
\hline NCM 3031 & & 1 & & & & & & & & 1 \\
\hline Pan 127 & & & & & & & & 1 & & 1 \\
\hline Redlans Pioneer & & & & & & & & 1 & & 1 \\
\hline Sabie & & 1 & & & & & & & & 1 \\
\hline SSB $10,30,40$ & 5 & 2 & & & & 1 & & 7 & & 15 \\
\hline Stormberg & 4 & & & & & 1 & & 3 & & 8 \\
\hline Stragonta & & & & & & 1 & & & & 1 \\
\hline SUG $65,68,70,72$ & & & & & & & & 6 & & 6 \\
\hline Taylor & & & & & & & & 1 & & 1 \\
\hline Umlazi & 2 & & & & & 2 & & 1 & & 5 \\
\hline Umtata & & & & & & & & 1 & & 1 \\
\hline Wartburg & 2 & 1 & & & & 2 & & 5 & 1 & 11 \\
\hline \multicolumn{11}{|l|}{ Small-seeded } \\
\hline Arctic & & 1 & & & & 1 & & 1 & & 3 \\
\hline Aurora & & & & & & 1 & & 1 & & 2 \\
\hline Breeding trials & & 1 & & & & & & 2 & & 3 \\
\hline $\mathrm{CNC}$ & & & & & & 1 & & & & 1 \\
\hline Coffee bean & & & & & & & & 1 & & 1 \\
\hline CSW 643 & & & & & & & & 1 & & 1 \\
\hline Heuningberg & & 1 & & & & & & & & 1 \\
\hline Kamberg & 1 & 1 & & & & 3 & & 3 & & 8 \\
\hline Kosi & & & & & & & & 2 & & 2 \\
\hline Mexico 235, 309 & & & & & & & & 2 & & 2 \\
\hline Mkuzi & 1 & & & & & 1 & & & & 2 \\
\hline Nandi & & 1 & & & & & & & & 1 \\
\hline NEP 2 & & & & & & & & 1 & & 1 \\
\hline Nuweveld & & & & & & & & 1 & & 1 \\
\hline Pan 122,125 & & & & & & & & 3 & & 3 \\
\hline Teebus & & & & & & 1 & & 4 & & 5 \\
\hline Yellow haricot & & & & & & & & 1 & & 1 \\
\hline \multicolumn{11}{|l|}{ P. coccineus } \\
\hline Bomba & & & & & & 1 & & & & 1 \\
\hline Egyptian Great & & & & & & 1 & & & & 1 \\
\hline SSN1 & 20 & & & & & 4 & & 5 & & 29 \\
\hline P. lunatus & & 1 & & & & & & & & 1 \\
\hline CIAT Trials & & & & & & & & 4 & & 4 \\
\hline Mixed beans & 1 & & & & & & & 3 & & 4 \\
\hline Unknown & 3 & 1 & & & & 3 & & 8 & 3 & 18 \\
\hline TOTAL & 69 & 16 & & 1 & & 43 & 4 & 118 & 4 & 255 \\
\hline
\end{tabular}


have originated from this region. Another possible reason for the extensive occurrence of race 8 in South Africa is that the majority of cultivars planted locally are susceptible to it. Races 1, 2, and 6 also appear to be well-established in South Africa, as each of them occurs on a variety of cultivars and in a number of localities. Three races (race 4, 7, and 9) were restricted to one or two localities, and it is likely that they have only recently been introduced. This hypothesis is supported by the fact that the only isolate belonging to race 4 was found on imported seed in a greenhouse trial, and does not occur in dry bean fields in South Africa. P. syringae pv. phaseolicola can be introduced into new areas on infected seed, and breeding programs or planting of foreign seed can easily result in the introduction and spread of new races in the country (8).

Various dry bean cultivars planted in South Africa were infected with halo blight in the field. This is of particular concern, since the disease can be damaging. One means of controlling the halo blight is by the introduction of a Disease-Free Seed Scheme in South Africa. The exclusion from the Scheme of large white kidney beans, which are highly susceptible to halo blight, has probably resulted in the spread of race 1 in the country. Race 1 was initially found on large white kidney beans only, but has since been isolated from a number of Phaseolus vulgaris cultivars (D. Fourie, unpublished data). The planting of a large number of foreign cultivars during the past 5 years in the South African production areas could also have contributed to the introduction of new races.

Breeding for resistance provides the most effective means of control of halo blight $(1,8)$. This study showed that the majority of cultivars planted locally are susceptible to $P$. syringae pv. phaseolicola. It is important that local and foreign breeding material should be screened for resistance and sources of resistance be introduced into local cultivars. Seven races are present in South Africa, and the possibility that new races could be introduced into the country exists. In order to breed for resistance, race non-specific resistance should be incorporated into local cultivars. Edmund and Wisc. HBR 72 are known to have race non-specific resistance and can be considered.

The inconsistent reactions of some isolates of $P$. syringae pv. phaseolicola, belonging to race 1 and 8 , on leaves and pods of differentials A43, Red Mexican U13, and Guatemala 196-B could indicate that different genes are controlling pod and leaf resistance. Similar reactions have been reported by Hale and Taylor (6). This phenomenon should be further investigated. Molecular techniques could assist in confirming the race identification in isolates where discrepancies occur.

$P$. syringae pv. phaseolicola isolates which produce a brown, diffusible pigment have been reported by several authors $(8,15,16)$. A similar pigment is often produced by isolates of Xanthomonas campestris pv. phaseoli (10). Two pigmentproducing bacteria, representing race 1 and race 6 , were isolated from material collected from Leslie, situated in the cooler production areas of South Africa. The isolates reported by Mabagala and Saettler (8) were identified as race 2 . It seems as if the pigment production is not limited to a specific race, but its function is still unknown.

\section{ACKNOWLEDGMENTS}

I thank Mara Liebenberg and Josephine Pholoholo for technical assistance; Nigel Lyons for supplying antiserum and reference cultures; Dawn Teverson and Julia Kornegay for supplying seed; Heinra Heenop for multiplication of seed; and Altus Viljoen for critical review of the manuscript.

\section{LITERATURE CITED}

1. Beebe, S. E., and Pastor-Corrales, M. A. 1991. Breeding for disease resistance. Pages 561-610 in: Common Beans, Research for Crop Improvement. A. Van Schoonhoven and O. Voysest, eds. CAB International, Wallingford.

2. Boelema, B. H. 1984. Infectivity titrations with race 2 of Pseudomonas syringae pv. phaseolicola in green beans (Phaseolus vulgaris). Phytophylactica 16:327-329.

3. Buruchara, R. A. 1983. Determination of pathogenic variation in Isariopsis griseola Sacc. and Pseudomonas syringae pv. phaseolicola (Burk., 1926) Young, Dye and Wilkie
1978. Ph.D. diss. University of Nairobi, Kenya.

4. Cheng, G. Y., Legard, D. E., Hunter, J. E., and Burr, T. J. 1989. Modified bean pod assay to detect strains of Pseudomonas syringae pv. syringae that cause bacterial brown spot of snap bean. Plant Dis. 73:419-423.

5. Edington, B. R. 1990. The identification of race 1 of Pseudomonas syringae pv. phaseolicola in South Africa. Annu. Rep. Bean Improv. Coop. 33:171.

6. Hale, C. N., and Taylor, J. D. 1973. Races of Pseudomonas phaseolicola causing halo blight of beans in New Zealand. N. Z. J. Agric. Res. 16:147-149.

7. King, E. O., Ward, M. K., and Raney, D. E. 1954. Two simple media for demonstration of pyocyanin and fluorescin. J. Lab. Clin. Med. 44:301-307.

8. Mabagala, R. B., and Saettler, A. W. 1992 Races and survival of Pseudomonas syringae pv. phaseolicola in Tanzania. Plant Dis. 76:678-682.

9. Patel, P. N., and Walker, J. C. 1965. Resistance in Phaseolus to halo-blight. Phytopathology 55:889-894.

10. Saettler, A. W. 1991. Diseases caused by bacteria. Pages 29-32 in: Compendium of Bean Diseases. R. Hall, ed. American Phytopathological Society, St. Paul, MN.

11. Schaad, N. W., ed. 1988. Laboratory Guide for Identification of Plant Pathogenic Bacteria, 2nd ed. American Phytopathological Society, St. Paul, MN

12. Sleesman, J. P., and Leben, C. 1978. Preserving phytopathogenic bacteria at $-70^{\circ} \mathrm{C}$ or with silica gel. Plant Dis. Rep. 62:910-913.

13. Taylor, J. D. 1970. Bacteriophage and serological methods for the identification of Pseudomonas phaseolicola (Burkh.) Dowson. Ann. App. Biol. 66:387-395.

14. Taylor, J. D., and Teverson, D. M. 1985. Halo-blight of Phaseolus bean. Page 87 in: Rep. Nat. Veg. Res. Stn. for 1984.

15. Taylor, J. D., Teverson D. M., Allen, M. A. and Pastor-Corrales, M. A. 1996. Identification and origin of races of Pseudomonas syringae pv. phaseolicola from Africa and other bean growing areas. Plant Pathol. 45:469-478.

16. Teverson, D. M. 1991. Genetics of pathogenicity and resistance in the halo-blight disease of beans in Africa. Ph.D. diss. University of Birmingham, Birmingham.

17. Wharton, A. L. 1967. Detection of infection by Pseudomonas phaseolicola (Burkh.) Dowson in white-seeded dwarf bean seed stocks. Ann. Appl. Biol. 60:305-312.

18. Zaiter, H. Z., and Coyne, D. P. 1984. Testing inoculation methods and sources of resistance to the halo blight bacterium (Pseudomonas syringae pv. phaseolicola) in Phaseolus vulgaris. Euphytica 33:133-141. 